\title{
EMPLOYMENT IN RURAL AREAS OF UKRAINE: TENDENCIES AND OPPORTUNITIES
}

\section{Serhiy MOROZ}

Sumy National Agrarian University

Department of Logistics and Production Management

160, H. Kondratyev St., Sumy, 40021, Ukraine

smorozmail@gmail.com

\begin{abstract}
The paper reviews the main tendencies and problems of rural employment in Ukraine. It has been concluded that the issue of rural employment could not be solved without a well-defined rural development policy and separately from other problems related to the rural regions. That is why it is necessary to implement in Ukraine the integrated rural policy which assumes a multisectoral approach to overcome the existing problems, to stimulate the economic diversity, and to expand non-agricultural activities in the rural areas. In order to develop the rural labour market it will be essential to achieve balance between the urban and rural areas, to create an attractive business environment, to build a stable rural financial system, and to develop physical and social infrastructures. In this paper the descriptive analysis is used to analyse tendencies and to identify opportunities for the increase in rural employment across the country.
\end{abstract}

Key-words: Rural employment, rural development policy, Ukraine.

\section{Introduction}

The market transformations had a strong impact on the socio-economic situation in rural areas of Ukraine. Due to the lack of a transparent rural development strategy, adverse effects were observed with respect to the quality of life of rural inhabitants. At present, the main problems of rural regions include a high unemployment rate, an increased migration of rural residents, reduction in the number of social infrastructure objects, deterioration of their material and technical base, and the lack of resources for maintenance and restoration of the productive potential of the rural areas (Borshchevsky et al. 2011).

Particular attention should be paid to a substantial decline of employment opportunities for rural inhabitants. It is connected with the fact that the Ukraine had relatively poorly diversified rural economy based primarily on agriculture. That is why the rural labor market has been strongly affected by agricultural reforms introduced since the 1990s.

During the reformation process the collective and State farms were liquidated in the agrarian sector. Instead, market-oriented private enterprises were set up. In consequence the number of jobs in these enterprises decreased sharply compared with collective and State farms. For a number of former employees the only opportunity to earn income was 
to work on household plots. However, this type of employment is characterized by the predominant use of manual labor, low income level, and lack of social guarantees. Nowadays, the situation regarding employment opportunities for rural inhabitants is quite the same. The significant share of the rural population still works in the household plot sector. Moreover, in about half of rural settlements there are no legal entities engaged in economic activities (State Committee of Ukraine for Statistics 2006a).

So, the situation in the rural regions is getting worse, including negative socio-economic tendencies, high level of unemployment, and the spreading rural poverty. In this context it is important to define measures to develop the rural labour market and create new employment opportunities for rural population.

The objective of this paper is to analyse rural employment tendencies and to determine possibilities for the improvement of the rural labour market in Ukraine, taking into consideration experience of the EU countries. The paper is based on the data of the State Statistics Service of Ukraine and the survey of the socio-economic state of rural settlements carried out by Gorshenin Institute.

\section{Background}

It should be noted that there is no common understanding of rural employment. In the EU FP7 project "RuralJobs" it was defined as 'any income-generating activity undertaken by an individual that takes place in a rural area'. This definition covers both the self-employed and employees and all sectors of the economy. It also covers 'teleworkers' who live and work in rural areas even if their job is nominally located in an urban centre (Rural Jobs project 2013).

As stated by Fieldsend (2011) there is no simple definition of rural employment but that a sustainable approach to exploiting natural capital together with the development of the other capitals of the territory via a place-based (i. e. territorial policy) approach can create jobs and encourage working age people either to stay in, or relocate to, rural areas.

To have a deeper understanding of the rural employment peculiarities, it is essential to pay attention to the concept of rural labour markets. These markets are viewed as functional systems in which the employment demand is driven by regional competitiveness, whilst the employment supply is partly a function of demography (including inter-regional migration), but also that of various socio-economic factors which determine participation rates, and of the qualitative aspects of the labour force often referred to as "human capital" (Copus et al. 2006).

Labour markets can be said to function well if they achieve two primary objectives concerning efficiency and fairness. On an efficient labour market all workers willing to work for the current wage rates are likely to quickly find suitable jobs that match their skills, education and experience. Fairness is most typically measured in terms of whether a worker is paid according to the value of his/her work. A well-functioning labour market is also characterized by adequate protection of workers against the risk of income loss by enabling workers to quickly find a new job or through the provision of suitable social protection (ILO 2008).

Rural employment can be divided into two types: agricultural and non-agricultural one. Research studies confirm that the reduction of the number of rural inhabitants en- 
gaged in agriculture is observed (see, for instance, Copus et al. 2006; OECD 2006). At the same time the non-agricultural sector is becoming more important for employment of the rural population and development of the rural areas.

According to Jonasson (2009) the rural non-agricultural employment (RNAE) includes all activities other than agricultural work on the own or somebody else's farm. A considerable share of the rural non-agricultural economy consists of the activities closely related to agriculture, such as food processing, transportation or marketing of agricultural goods. It also includes activities such as mining, construction, domestic services, and tourist-related services, with little or no connection to agriculture. RNAE is increasingly emphasized as a potential pathway out of rural poverty for people who are unable to secure their income in agriculture.

That is why special attention is given to the employment diversification, which is a major livelihood strategy in rural areas. The employment diversification is a dynamic socio-economic process within the framework of which the rural households extend the range of income sources in their income portfolio. Such diversified incomes are usually based on a mix of the farm and non-farm incomes. The employment diversification leads to an increase in the number and mix of income sources. Thus, employment diversification rises with the number of income sources, the equity of their distribution, and their dissimilarity (Buchenrieder et al. 2007).

Five strategic orientations which target the major driving forces for rural employment, namely: natural, financial, human, physical and social capital, and the interactions between them, could be the focus for future rural employment strategies. They are as follows:

- Encourage the development of key growth sectors

- Reinforce the local rural economy

- Improve skills and labour market participation in rural areas

- Develop infrastructure and services

- Ensure proper implementation of the strategy through support actions (Fieldsend 2011).

\section{Rural employment tendencies}

It is worth noting that the population has very limited employment opportunities in the rural regions of Ukraine. This problem is one of the most important in the rural areas. According to the all-Ukrainian sociological survey conducted by Gorshenin Institute, $52.9 \%$ of rural inhabitants mentioned unemployment as the main issue in their villages (Gorshenin Institute 2013a).

The drastic changes in the Ukrainian rural employment occurred due to transition from a centrally planned to a market economy. They were accompanied by the influence of many factors. First of all, the employment was affected by unfavourable demographic characteristics of the rural regions. The significant share of the population still lives in the rural areas (in 2012-31.2\%). However, in absolute terms, the rural population declined from 19.2 million people in 1979 to 14.2 million people in 2012, i.e. by 26.0\%. According to the existing methodology there are two types of settlements in Ukraine: urban and rural. The urban type settlements are the population centres which are approved by legislation as towns and urban type settlements. The remaining population centres are rural (State Statistics Service of Ukraine 2013e). 
The decline in the number of rural population was aggravated by the deterioration of the rural population structure (Fig. 1). While the share of people aged 15-59 grew from $57.6 \%$ to $60.7 \%$ between 1979 and 2012, the percentage of children (0-14 years old) fell from $22.1 \%$ to $16.2 \%$. Besides, a proportion of rural residents aged 60 and over increased from $20.3 \%$ to $23.1 \%$. As a result of the above-mentioned changes, the average age of the rural population grew from 38.0 years to 40.7 years (Institute for Demography and Social Studies of the National Academy of Sciences of Ukraine 2007; State Statistics Service of Ukraine 2013c).

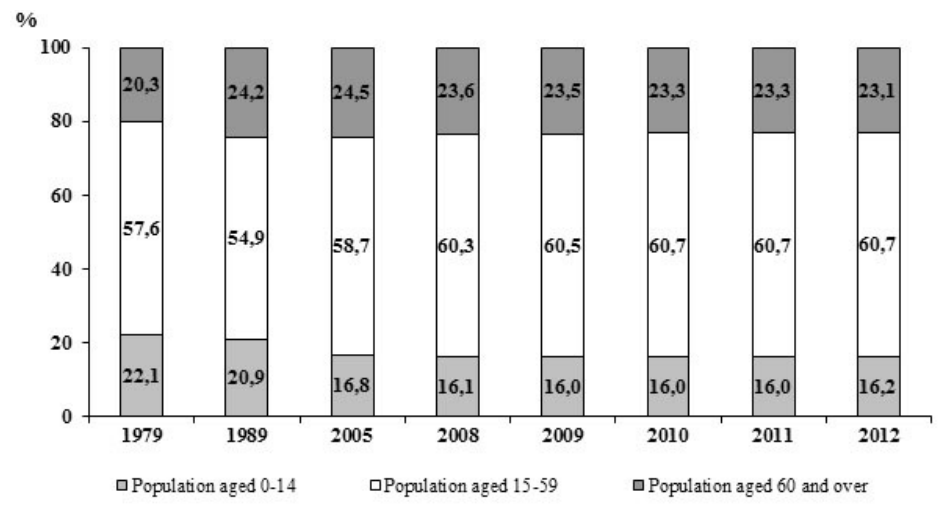

Fig. 1. Distribution of the rural population in Ukraine, 1979-2012, by broad age group (\%)

Source: Own work based on the data of Institute for Demography and Social Studies of the National Academy of Sciences of Ukraine 2007; State Statistics Committee of Ukraine 2006b, 2009b, 2010c; State Statistics Service of Ukraine 2011, 2012b, 2013e.

However the rural regions of Ukraine are quite different with respect to their demographic indicators. For example, while analysing the change in the number of the rural population in 2006-2013, it should be noted that the smallest decrease of this indicator occurred in the Karpatsky and Prychornomorsky economic regions: by $1.8 \%$ and $3.0 \%$, respectively (Table 1). Its most significant decline was found in the Shidny (by 9.4\%) and Donetsky (by 8.5\%) economic regions. The similar situation was observed with respect to the average age of rural residents. In 2013, the youngest population lived in Karpatsky and Prychornomorsky regions (38.4 and 39.0 years). At the same time the average age of rural inhabitants of Shidny and Tsentralny regions was substantially higher ( 43.3 and 43.1 years, respectively). Thus, it can be clearly seen that the most advantageous demographic characteristics could be found in the economic regions in the western and southern parts of Ukraine compared with the eastern and central parts of the country.

The rural regions continue to play a significant role in the employment of the Ukrainian population. It should be noted that in Ukraine the employed persons include those aged 15-70 who:

a) worked at least one hour during a referenced week:

- they were self-employed or employed by others, or worked in their own (family) enterprise and received money or remuneration in-kind,

- they worked for free in an enterprise, in household member owned business, or on an individual farm in order to sell products as a result of this activity,

b) were temporarily absent from work, i.e. they formally had a job, their own enter- 
prise (own business); however, they did not work during the surveyed period for some reason (State Statistics Service of Ukraine 2013b).

In 2000-2012, the number of employed persons in rural areas decreased from 6,429.3 thousand to 6370.3 thousand. At the same time, the employment rate in rural areas increased from $57.3 \%$ to $62.7 \%$. For a more detailed analysis let's consider the distribution of the employed rural population by employment status. In 2012, this distribution was as follows: hired workers $-59.2 \%$, employers $-0.6 \%$, self-employed $-39.4 \%$, and unpaid family members $-0.8 \%$ (State Statistics Service of Ukraine, 2013b).

Table 1. The permanent rural population of Ukraine in 2006-2013, by economic region*, thousand persons (at the beginning of the year)

\begin{tabular}{|c|c|c|c|c|c|}
\hline Economic regions & 2006 & 2011 & 2013 & 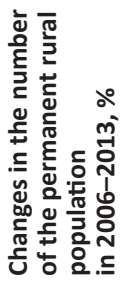 & 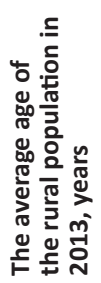 \\
\hline Karpatsky & 3156.6 & 3099.9 & 3098.7 & -1.8 & 38.4 \\
\hline Polisky & 2174.3 & 2060.4 & 2035.7 & -6.4 & 40.7 \\
\hline Podilsky & 2180.9 & 2041.8 & 2003.8 & -8.1 & 42.5 \\
\hline Shidny & 1638.1 & 1518.2 & 1483.5 & -9.4 & 43.3 \\
\hline Tsentralny & 1325.7 & 1236.0 & 1218.2 & -8.1 & 43.1 \\
\hline Prydniprovsky & 1436.4 & 1357.3 & 1334.5 & -7.1 & 41.5 \\
\hline Prychornomorsky & 2435.9 & 2369.5 & 2362.3 & -3.0 & 39.0 \\
\hline Donetsky & 779.1 & 729.2 & 713.2 & -8.5 & 43.0 \\
\hline Ukraine & 15127.0 & 14412.3 & 14249.9 & -5.8 & 40.7 \\
\hline
\end{tabular}

* According to the methodology of the Council of Productive Forces Study of Ukraine of the National Academy of Sciences of Ukraine (State Statistics Service of Ukraine, 2012a), Ukraine can be divided into 8 economic regions which include the following oblasts: Shidny: Poltava, Kharkiv, and Sumy oblasts; Donetsky: Donetsk and Luhansk oblasts; Prydniprovsky: Zaporizhya, Kirovohrad, and Dnipropetrovsk oblasts; Prychornomorsky: Autonomous Republic of Crimea, Odesa, Mykolayiv, and Kherson oblasts; Podilsky: Ternopil, Vinnytsya, and Khmelnytskiy oblasts; Tsentralny: Cherkasy and Kyiv oblasts; Karpatsky: Chernivtsi, Zakarpattya, Ivano-Frankivsk, and Lviv oblasts; Polisky: Rivne, Volyn, Zhytomyr, and Chernihiv oblasts.

Source: Own work based on the data of the State Statistics Committee of Ukraine (2010b), State Statistics Service of Ukraine (2013c, 2013d).

Particular attention should be given to the category of the self-employed persons. The majority of these people are running individual farms which mainly rely on the manual labour. This type of employment does not require a high level of technical and technological skills. Actually, the self-employed people neither receive State support in respect of the production activities nor for the enhancement of their knowledge and practical skills in order to adapt to the changes in the employment system (Betliy et al. 2006).

In Ukraine, employed persons also include people who work in the informal sector of the economy. An enterprise in this sector has to be oriented towards market regarding economic activity, employ up to 5 workers and not registered. Table 2 shows data on the rural population employment in the informal sector. It shows that the proportion of rural 
inhabitants involved in the sector is quite high (50.7\% and 47.5\% in 2007 and 2012, respectively). According to the national methodology, the informal sector includes persons employed in the unregistered enterprises which by their size (the number of workers) are classified as family businesses. This sector also involves people who work in the official sector based on a verbal agreement with the employer, namely without an official labour contract. In 2012, the proportion of hired workers in the total number of rural population employed in the informal sector was only $17.4 \%$.

Table 2. The rural population employed in the informal sector of the Ukraine economy, 2005-2012

\begin{tabular}{|c|c|c|c|c|c|c|c|c|c|}
\hline & 2005 & 2006 & 2007 & 2008 & 2009 & 2010 & 2011 & 2012 & $\begin{array}{l}2012 \\
(+,-) \text { to } \\
2005\end{array}$ \\
\hline \multicolumn{10}{|l|}{$\begin{array}{l}\text { Rural population } \\
\text { employed in the } \\
\text { informal sector of the } \\
\text { economy: }\end{array}$} \\
\hline $\begin{array}{l}\text { - the share of the } \\
\text { total number of the } \\
\text { employed rural popu- } \\
\text { lation, \% }\end{array}$ & 47.5 & 50.5 & 50.7 & 47.9 & 46.4 & 47.7 & 48.3 & 47.5 & 0.0 \\
\hline $\begin{array}{l}\text { - total, thousand } \\
\text { persons }\end{array}$ & 3125.4 & 3303.9 & 3341.9 & 3140.5 & 3019.7 & 3085.2 & 3115.3 & 3028.7 & -96.7 \\
\hline \multicolumn{10}{|l|}{ including: } \\
\hline \multirow{3}{*}{$\begin{array}{l}\text { 1) hired workers: } \\
\text { - thousand persons } \\
\text { - the share of the } \\
\text { total number of the } \\
\text { rural population em- } \\
\text { ployed in the informal } \\
\text { sector, \% }\end{array}$} & & & & & & & & & \\
\hline & 350.6 & 394.6 & 429.6 & 525.0 & 524.0 & 518.0 & 522.5 & 528.2 & +177.6 \\
\hline & 11.2 & 11.9 & 12.9 & 16.7 & 17.4 & 16.8 & 16.8 & 17.4 & +6.2 \\
\hline \multicolumn{10}{|l|}{ 2) non-hired workers: } \\
\hline - thousand persons & 2774.8 & 2909.3 & 2912.3 & 2615.5 & 2495.7 & 2567.2 & 2592.8 & 2500.5 & -274.3 \\
\hline $\begin{array}{l}\text { - the share of the } \\
\text { total number of the } \\
\text { rural population em- } \\
\text { ployed in the informal } \\
\text { sector, \% }\end{array}$ & 88.8 & 88.1 & 87.1 & 83.3 & 82.6 & 83.2 & 83.2 & 82.6 & -6.2 \\
\hline
\end{tabular}

Sources: Own work based on the data of the State Statistics Committee of Ukraine (2009a), State Statistics Service of Ukraine (2013b).

The spread of informal employment in rural regions was caused by the reduction of jobs in the agricultural enterprises. The unemployed rural population was forced to seek income and employment opportunities in the informal sector. This type of employment is particularly important for socially vulnerable groups of the rural population, namely: rural youth, pensioners, as well as people with a low level of education or without education, i.e. categories of the labour force for which it is difficult to compete in the agricultural labour market for various reasons. Employment in the informal sector mitigates to some extent the negative impact of the agrarian reforms. However, the members of rural population who work in the sector are not covered by the State social insurance and pro- 
tection. Therefore, this type of employment cannot be considered as an effective way for addressing the needs of the rural population (Mahsma 2013).

Between 2005 and 2012 the rural unemployment rate which had been calculated in accordance with the methodology of the International Labour Organization grew from $5.7 \%$ to $7.4 \%$ (Table 3 ). Also, the rural economy was adversely affected by the age group distribution of the unemployed persons. The increase in unemployment rate occurred in all age groups (excluding the population aged 60-70). As a result, in 2012, the highest level of unemployment was observed in the 15-24 and 25-29 age groups $-14.6 \%$ and $9.4 \%$, respectively. Thus, the problem of unemployment affected in particular the economically active rural population. It should also be mentioned that young people in rural areas were more involved in economic activities on the informal employment basis, primarily on the individual farms where almost two thirds of young persons aged 15-24 were employed (Institute for Demography and Social Studies of the National Academy of Sciences of Ukraine, 2007).

Table 3. Rural unemployment rate by age groups (according to the methodology of the International Labour Organization) (\%), 2005-2012

\begin{tabular}{|l|r|r|r|r|r|r|r|r|c|}
\hline & $\mathbf{2 0 0 5}$ & $\mathbf{2 0 0 6}$ & $\mathbf{2 0 0 7}$ & $\mathbf{2 0 0 8}$ & $\mathbf{2 0 0 9}$ & $\mathbf{2 0 1 0}$ & $\mathbf{2 0 1 1}$ & $\mathbf{2 0 1 2}$ & $\begin{array}{c}\mathbf{2 0 1 2} \\
(+\mathbf{+}-\mathbf{-}) \mathbf{t o} \\
\mathbf{2 0 0 5}\end{array}$ \\
\hline $\begin{array}{l}\text { The total rural popula- } \\
\text { tion aged 15-70 }\end{array}$ & 5.7 & 5.8 & 5.4 & 5.7 & 7.2 & 7.1 & 7.5 & 7.4 & +1.7 \\
\hline $\begin{array}{l}\text { of which by age groups } \\
\text { (years): }\end{array}$ & & & & & & & & & \\
15-24 & 11.1 & 10.1 & 10.2 & 10.3 & 13.2 & 12.6 & 16.1 & 14.6 & +3.5 \\
$25-29$ & 6.3 & 6.7 & 6.2 & 6.6 & 8.3 & 8.4 & 9.1 & 9.4 & +3.1 \\
$30-34$ & 6.4 & 6.3 & 5.5 & 5.6 & 7.2 & 7.9 & 7.6 & 7.6 & +1.2 \\
$35-39$ & 6.5 & 6.1 & 5.8 & 6.0 & 7.3 & 8.7 & 7.0 & 6.6 & +0.1 \\
$40-49$ & 5.4 & 5.7 & 4.9 & 5.7 & 7.2 & 6.5 & 6.7 & 6.8 & +1.4 \\
$50-59$ & 4.0 & 4.4 & 4.3 & 4.2 & 5.3 & 4.8 & 5.0 & 5.5 & +1.5 \\
$60-70$ & 0.1 & 0.0 & 0.0 & - & - & - & 0.0 & 0.0 & -0.1 \\
\hline
\end{tabular}

Source: Own work based on the data of the State Statistics Committee of Ukraine (2009a, 2010a), State Statistics Service of Ukraine (2013b).

In 2013, the substantial proportion of rural population worked outside the place of residence: in other towns and settlements $-31.1 \%$, and abroad-16.3\% (Fig. 2). Agriculture and the subsistence economy were the main economic sources of livelihood for $28.9 \%$ and $28.4 \%$ of rural inhabitants, respectively. This confirms that agriculture remains one of the major sectors, which provides employment and income-earning opportunities for the rural population. At the same time, a gradual development of other economic activities was observed in the rural areas. For instance, the respective percentages for respondents earning income from trade and private business were $24.6 \%$ and $14.8 \%$ (Gorshenin Institute 2013b).

Several peculiarities concerning agricultural employment can be mentioned (Figure 3). The total number of persons involved in agricultural activities fell from 4.3 million persons in 2000 to 3.5 million persons in 2012, i.e. by 18.6\%. In this period, the share of 
agriculture in total employment of the Ukrainian population fell from $21.5 \%$ to $17.2 \%$. In the EU countries, in 2011, this indicator was 5.3\%. However, there were considerable differences of this indicator among the EU countries. In this respect, Ukraine can be compared to Romania, Bulgaria and Poland which have the highest shares of agricultural employment in the EU (32.6\%, 19.9\% and $12.7 \%$, respectively) (European Commission 2012).

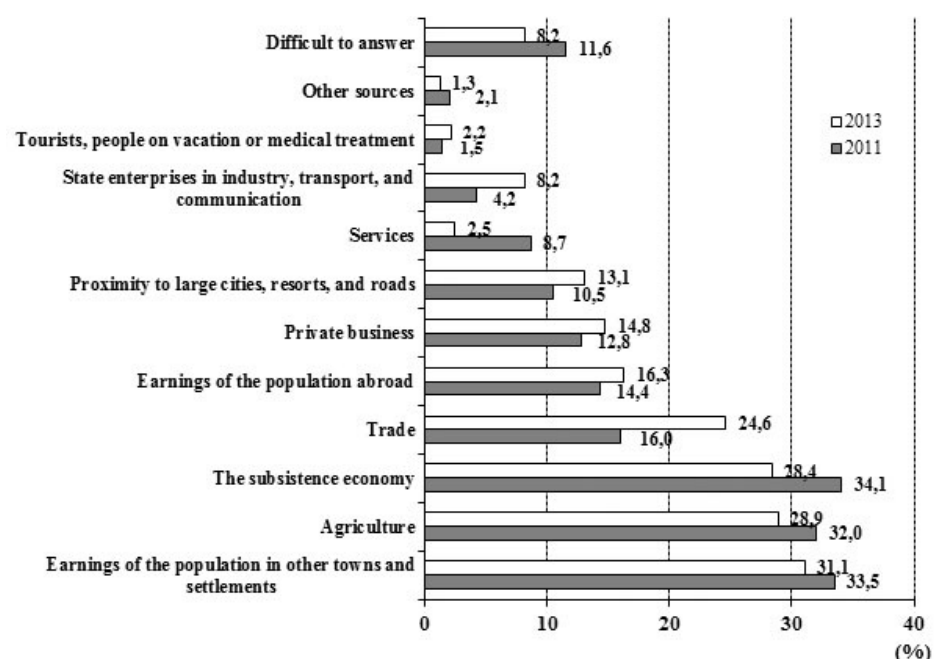

Fig. 2. Economic sources of livelihood in villages (\%)

Note: respondents had a possibility to select up to three answer options.

Source: Gorshenin Institute (2013b).

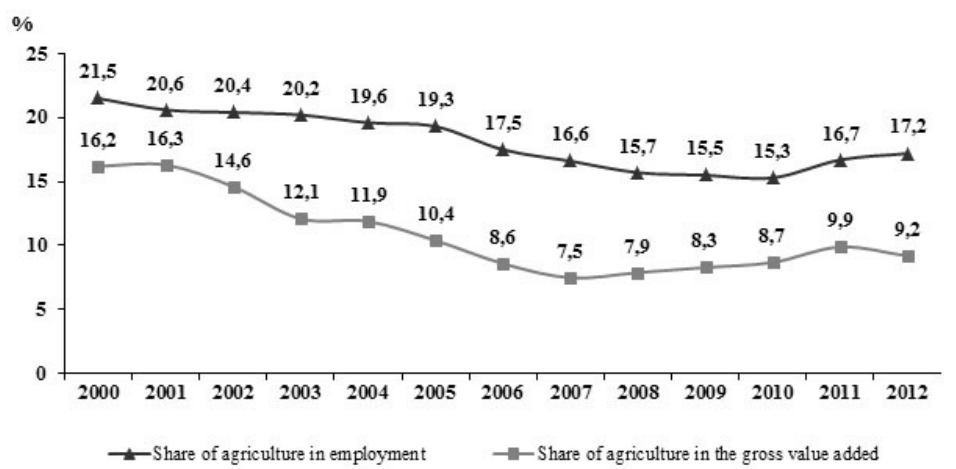

Fig. 3. The share of agriculture in employment and the gross value added in Ukraine (\%), 2000-2012 Source: Own work based on the data of the State Statistics Committee of Ukraine $(2003,2008)$, State Statistics Service of Ukraine (2013e).

It should be noted that during 2000-2012, the proportion of hired agricultural workers in the total number of people involved in agriculture decreased from $63.5 \%$ to $21.2 \%$ (State Statistics Committee of Ukraine 2008; State Statistics Service of Ukraine 2013e). Also, there was the highest percentage of the population working in the informal sector of agriculture among all branches of economy. In 2012, this indicator was $64.8 \%$ (State Statistics Service of Ukraine 2013b). 
It should be noted that the share of agriculture in the gross value added decreased from $16.2 \%$ in 2000 to $9.2 \%$ in 2012 . The high level of agricultural employment and the simultaneous substantial decline of the share of agriculture in the gross value added indicate that the excess labour force is concentrated in the agricultural sector. This can be also illustrated by the fact that in 2012 the number of skilled workers looking for a job in agriculture, forestry, and fishery was on average 33 people per vacancy, while in all other types of economic activities there were only 11 people per vacancy (State Statistics Service of Ukraine 2013e).

Thus, the crisis situation concerning employment of rural inhabitants, especially among young people, is observed in Ukraine. This situation takes place not only because of the worsening indicators of economic activity, but also because of unfavourable demographic indicators in the rural areas, a decline in income and cultural levels of rural dwellers and people engaged in agriculture, and deterioration of social infrastructure (Yakuba 2007).

\section{Perspectives of Rural Employment in Ukraine}

In order to understand why these unfavourable tendencies in the rural employment take place in Ukraine, several factors have to be taken into consideration. From our point of view the most significant obstacle is the lack of a well-defined rural policy in the country. So far, the development of rural regions in Ukraine has been mainly seen from the angle of agricultural production. However, the research studies, carried out for example by the Organization for Economic Cooperation and Development (OECD), show that the rural policy which is mainly based on the agriculture could not use all favourable factors, ensure the effective development of rural territories, and solve the issue of rural employment (OECD 2006).

It should be taken into account that the agricultural reform strategy implemented in Ukraine has some peculiarities. From the beginning of the agrarian reform its main directions consisted in the development of private ownership, transformation of collective and State farms into market-oriented private legal structures, and creation of the competitive agricultural production. However, the slow pace of the agricultural reform and inconsistency in its implementation significantly complicated the restructuring process. During 1990-2012, the level of gross agricultural output on the farms of all types, estimated at the level of 2010 comparable prices, shrank from 282.8 billion hryvnias to 223.3 billion hryvnias, or by $21.0 \%$. Whereas production in agricultural enterprises decreased by $43.2 \%$, it grew by $31.8 \%$ on the individual plots. As a result, the proportion of gross agricultural output produced in agricultural enterprises declined from $70.4 \%$ in 1990 to $50.7 \%$ in 2012. In contrast to this, in 1990-2012, the share of household plots in gross agricultural output increased by $19.7 \%$ and amounted to $49.3 \%$. Moreover, the significant number of agricultural enterprises was unprofitable (21.4\% in 2012) (State Statistics Service of Ukraine 2013a).

In this context some researchers point out that the rural non-farm employment is a pillar of rural development policy and a critical factor for providing rural employment and income in the long-term perspective, (see, for instance: Nivyevskiy and von Cramon-Taubadel, 2006). According to Lerman et al. (2007) only $26 \%$ of corporate farms and 
$13 \%$ of individual farms in Ukraine reported any non-agricultural activities. The non-farm sector was more developed in the EU countries. In 2007, 34.8\% of all EU farmers were engaged in gainful activities other than their farm work. The respective figures for Romania, Bulgaria, and Poland were 37.1\%, 39.3\%, and 37.7\%. The proportion of employment in the non-agricultural sector in rural areas of the European Union was $86.7 \%$ in 2009 (European Commission 2012).

We share the point of view of some researchers (for instance, Lerman et al. 2007) that the scarcity of off-farm employment opportunities in rural areas is perhaps the greatest barrier preventing an increase in rural incomes. It is also relevant to mention that because of a high share of rural population working in the agricultural sector the transformation process of the rural labour market and development of the rural economy in Ukraine might take more time and be more complicated compared to other countries with economy in transition.

Taking into account the specific features of the rural employment issue, as well as the significant interdependence of all economic activities in rural settlements, it is necessary to work out a transparent rural development policy and to define its strategic goals for Ukraine. It is our understanding that the special attention should be paid to the following long-term aims of the rural policy in order to ensure the effective development of the rural labour market:

- Improvement of competitiveness and diversification of the rural economy,

- Introduction of measures to improve the quality of rural life and to increase rural incomes.

Diversification of the rural economy and, in particular, the rural employment should one of the key elements of the policy. This policy element could provide possibilities for rural residents to switch over from agriculture as a primary source of incomes to alternative non-farm activities.

The human capital is another factor which has strongly affects development of the rural labour market. It provides good opportunities to reduce poverty in rural areas and the income differentiation among rural residents, as well as to narrow the gap between urban and rural settlements in this respect (see, for instance: The International Bank for Reconstruction and Development / The World Bank 2007). It is worth noting that the actual level of the quality of human capital in rural settlements is extremely low in Ukraine. Also, the level of education and special training in the rural areas continues to lag behind urban areas in this respect. In 2012, only $11.8 \%$ of rural people aged $15-70$ completed higher education, which was $18.6 \%$ less compared with urban inhabitants. $16.2 \%$ of rural dwellers had only secondary education. Moreover, $1.7 \%$ of the rural population had only primary education or was illiterate (State Statistics Service of Ukraine 2013b). This is why special educational and training programs should be introduced in the rural districts. In this respect, the attention could be paid, for instance, to the experience of the Essex Rural Partnership. The training schemes and practical courses for rural residents were initiated in Essex on the basis of colleges, schools, and libraries. The courses comprise basic skills such as literacy, numeric skills, key life skills and IT improvement skills. Besides, in order to facilitate access to these training programs of rural inhabitants, mobile facilities are used, such as the buses containing IT equipment with Internet access that travel across the rural communities (Council of European Municipalities and Regions 2003).

With the human capital considered at the level of an individual, the social capital is related to social groups of people. The level of social capital is determined on the basis of 
the ability of inhabitants to establish relations with each other and to form social groups which could be able to carry out work jointly in order to achieve the common goals. That is why the most significant function of this type of capital is the social and integrated direction.

Go et al. (2013) distinguish three social capital dimensions and their role in connecting local and external stakeholders:

- from the cognitive perspective, the social capital present in the destination is the local stakeholders' possession of fine-grained understanding of local opportunities and weaknesses,

- from a structural perspective, the local stakeholders may interpret the strength in their social network ties as an organizational capability and main benefit,

- embedded governance knowledge from a relational perspective allows the formation of a destination decision support system.

It is worth noting that under the command economy the majority of socio-economic issues of Ukrainian rural settlements were solved by the State. Today, the State has very limited possibilities in this respect. However, the substantial proportion of the rural population still hopes that someone will come and solve all problems. Also, the lack of social and integrated links in Ukrainian rural communities is one of unfavourable factors that hamper their further development. We suggest that, based on the formation of social capital, it is necessary to build relationships and the trust between various social groups and, as a result, to overcome existing issues in rural Ukraine. Moreover, due to the activation of social capital people will become confident about their abilities to improve the situation and actively support rural reforms.

In this context, it is important to decentralize the management of rural territories, which envisages the use of the bottom-up approach and increase in the power of local rural authorities. To improve the quality of social capital in Ukraine it will be particularly helpful to pay attention to the EU LEADER Community Initiative, which is well known because of its innovative nature, and to use an approach similar to the LEADER program to promote the integrated development of rural territories.

At the same time the attention should be paid to the fact that rural regions are not homogeneous and they have quite diverse demographic and socio-economic characteristics. As a result, the LEADER program may have a different impact on the rural labour market as far as regions and economic sectors are concerned (see, for instance: Metis $\mathrm{GmbH}, \mathrm{AEIDL}$ and CEU 2010). With regard to a possibility to respond to local employment problems, one area might be very successful and another not at all, depending on the type of activity, local entrepreneurs' participation, technical and financial assistance offered, and availability of training and skilled workers. Also, the LEADER results show that job creation in the rural areas is better solved as a policy objective when it is set as an indirect rather than as a direct aim (Saraceno 1999). Thus, to achieve positive changes in the rural labour market it is necessary to carry out a detailed economic analysis of rural regions before the implementation of the LEADER program.

One of the main elements of the LEADER method is the local action group characterized by decentralized financing, co-operation and partnerships of the public and private stakeholders. The LEADER method shows its organizational originality at the local level in the role and functioning of the Local Action Groups which play a key role as the "crossroads" of the complex system of vertical and horizontal relationships (OECD 2006). The 
introduction of the LEADER program will be an important step towards the effective and manageable rural development policy, responding more quickly and flexibly to needs of the rural population. Besides, the experience of the European Union in the rural governance could be valuable for Ukraine because it provides possibilities for rural people not only to express their points of view on various issues, but also to participate directly in the decision-making process. Ukraine has already had some positive experience in the implementation of elements of the above-mentioned programs using the bottom-up approach (Community Based Approach to Local Development Project 2013). Thus, there is no doubt that it is important to continue these programs and to expand their activities in all regions of Ukraine.

While considering the factors which have a strong impact on the rural development, it is worth noting the importance of providing a favourable business environment in rural regions. It has a significant impact on the viability, competitiveness and growth of the rural economy, and, respectively, on the rural labour market. Currently, the business environment in Ukraine is poorly developed. According to the World Bank study of the business environments, Ukraine occupies only the 112th place among 189 countries (The International Bank for Reconstruction and Development /The World Bank 2013). This situation is hampered by the flawed legal, tax, and regulatory systems. It is important to simplify all these systems and to adjust them to the needs of rural enterprises. The rural business activities could be stimulated through the creation of business incubators and implementation of special training programs. Besides, it is necessary to provide the rural entrepreneurs with suitable access to market information so as to allow them to carry out their activities more effectively and to react timely to the changes in the market environment, to introduce technical innovations, etc. In this context, the provision of such information and consulting services has the particular importance to encourage development of the rural entrepreneurship. This can be done through further expansion of the national extension network in the rural districts, which should provide services to both farms and non-agricultural enterprises.

The enhancement of the rural labour market and the decrease of the share of the rural population living below the poverty threshold depend significantly on the development of the rural financial system. The efficient rural financial markets and financial services also provide good opportunities for the economic growth of rural territories, stimulation of rural entrepreneurship and reduction of the risk for various types of business activities. So far, the sustainable rural financial markets in Ukraine have not come into being yet. By contrast, especially in 1990s, among the major instruments of rural policies there were government-provided or government-subsidized targeted credits. In addition, the rural policy instruments were frequently changed, and consequently they had an impact mainly on the symptoms of rural finance issues instead of their fundamental reasons (Sedik 2003). That is why it is important to promote the development of rural credit cooperation (including credit unions, financial cooperatives and their networks, etc.) so as to facilitate the access of rural businesses to credit resources and to reduce their cost for borrowers.

Also, the lack of the balance between urban and rural settlements in terms of their social and economic conditions as well as employment opportunities is observed. Thus, the appropriate measures should be carried out to encourage the complementary development of urban and rural areas. It is necessary to balance employment opportuni- 
ties which are important for the sustainable development of urban and rural territories. The particular attention should be devoted to the principle of subsidiarity which provides for the most active role of local and regional authorities in tackling the problem of rural unemployment. The local bodies should promote social integration processes and disseminate best practice. It would be relevant to mention the EU experience concerning the improvement of the interaction between urban and rural settlements in this respect (Council of European Municipalities and Regions 2003). The regional authorities need in turn to guarantee the effective distribution of public funds to local budgets.

It is also essential to develop the social infrastructure in order to promote rural employment and to improve the attractiveness of the rural areas in terms of living conditions. Unfortunately, as a result of a deep crisis of the rural economy the substantial share of villages did not have social infrastructure facilities, such as schools (53\%), pre-school organizations (69\%), health care institutions (33\%), and club-houses (42\%). Similar situation was observed with respect to other social infrastructure elements (Borodina et al. 2010). The negative tendencies related to this infrastructure significantly complicate the development of rural regions. In order to overcome the above-mentioned obstacles the attention should be paid to the adoption of appropriate measures in Ukraine using the integrated rural development approach. Besides, in order to create new rural jobs and to increase the attractiveness of rural territories in social and business terms the attention should be given to development of the economic infrastructure, transport, and information technologies, especially the Internet.

\section{Conclusion}

As a result of the above-mentioned considerations, it can be concluded that the issue of rural employment cannot be solved without a well-defined rural development policy, separately from other problems related to the rural regions. That is why it is necessary to implement in Ukraine the integrated rural policy, which provides for the multisectoral approach to overcome existing issues, to stimulate the economic diversity, and to expand non-farm activities in rural areas.

In this context, it will be particularly important to introduce in Ukraine a program similar to the EU LEADER initiative that gives good opportunities for rural communities to be involved directly in resolving problems of the rural settlements (including the rural employment), to coordinate actions of various participants of the rural development processes, to unlock the long-term potential of rural regions, and to provide favourable conditions for the enhancement of the quality of human and social capital. Also, it will be essential to achieve the balance between the urban and rural areas, to create an attractive business environment, to build a stable rural financial system, and to develop the physical, economic, and social infrastructures.

At the same time, the attention should be paid to the fact that rural regions are not homogeneous and they have quite diverse demographic and socio-economic characteristics. That is why the LEADER program may have a different impact on the rural labour market as far as the regions and economic sectors are concerned. Thus, to achieve positive changes in the rural labour market, it is necessary to carry out a detailed economic analysis of rural regions before the implementation of the LEADER program. 


\section{References}

Betliy M., Borodin S., Borodina O., Feher I., Haydutsky A., Hazners Y., Hulbe I., Karlova N., Lekse O., Mohylny O., Mokshyna P., Moldavan L., Onyshchenko O., Petrechenko V., Popova O., Popp D., Potori P., Prokopa I., Serova E., Shubravska O., Shyk O., Skurska N., Zinchuk T., 2006, The Agrarian Sector of Ukraine on the Way to Eurointegration, Uzhgorod, IVA.

Borodina O., Prokopa I., Yurchyshyn V., Rykovska O., Yarovyy V., Popova O., Mishchenko N., Kutsmus N., Lukyanova M., Zinchuk T., Borodina O., Kyryzyuk S., Fursenko I., Pavlov V., Unguryan V., 2010, Theory, Policy and Practice of Rural Development, Institute of Economics and Forecasting of the National Academy of Sciences of Ukraine, Kyiv.

Borshchevsky V., Prytula H., Krupin V., Kulish I., 2011, Problems and Perspectives of Development of Rural Areas of Ukraine (on the example of Karpatsky region): Research and Analytical Report, National Academy of Sciences of Ukraine, Institute for Regional Studies, Lviv.

Buchenrieder G., Möllers J., Happe K., Davidova S., Fredriksson L., Bailey A., Gorton M., Kancs D., Swinnen J., Vranken L., Hubbard C., Ward N., Juvančič L., Milczarek D., Mishev P., 2007, Conceptual Framework for Analysing Structural Change in Agriculture and Rural Livelihoods, Discussion Paper, 113, Leibniz Institute of Agricultural Development in Central and Eastern Europe, Halle (Saale), Germany, pp. 1-83.

Community Based Approach to Local Development Project, 2013, About CBA Project, http://cba. org.ua/en/about/about-cba

Copus A., Hall C., Barnes A., Dalton G., Cook P., Weingarten P., Baum S., Stange H., Lindner C., Hill A., Eiden G., McQuaid R., Grieg M., Johansson M., 2006, Study on Employment in Rural Areas, SAC. Council of European Municipalities and Regions, 2003, Complementarities between Urban and Rural Areas in Promoting Employment and Social Inclusion, Paris/Brussels.

European Commission, 2012, Rural Development in the European Union. Statistical and Economic Information Report 2012, Directorate-General for Agriculture and Rural Development.

Fieldsend A., 2011, Rural Europe 2+2+: A conceptual Framework for a Rural Employment Policy, Studies in Agricultural Economics, 113, pp. 145-151.

Go F., Trunfio M., Della Lucia M., 2013, Social Capital and Governance for Sustainable Rural Development, Studies in Agricultural Economics, 115, pp. 104-110.

Gorshenin Institute, 2013a, The Socio-economic Situation of the Contemporary Ukrainian Village. Part 1, http://institute.gorshenin.ua/researches/126_sotsialnoekonomichne_stanovishche.html Gorshenin Institute, 2013b, The Socio-economic Situation of the Contemporary Ukrainian Village. Part 2, http://institute.gorshenin.ua/researches/128_sotsialnoekonomichne_stanovishche.html

ILO, 2008, Report IV. Promotion of Rural Employment for Poverty Reduction. Fourth Item on the Agenda, International Labour Conference, 97th Session, Geneva.

Institute for Demography and Social Studies of the National Academy of Sciences of Ukraine, 2007, Population of Ukraine. Social and Demographic Problems of Rural Area, Kyiv.

Jonasson E., 2009, Earnings Differentials in the Rural Labor Market: Does Non-agricultural Employment Pay Better? Working Papers 2008:7, Lund University, Department of Economics, http:// project.nek.lu.se/publications/workpap/Papers/WP08_7.pdf

Lerman Z., Sedik D., Pugachov N., Goncharuk A., 2007, Rethinking Agricultural Reform in Ukraine, Studies on the Agricultural and Food Sector in Central and Eastern Europe, IAMO, Halle (Saale), vol. 38.

Mahsma M., 2013, Informal Employment of the Rural Population of Ukraine, Businessinform, 7, pp. 175-180.

Metis GmbH, AEIDL and CEU, 2010, Ex-post Evaluation of LEADER+. Final Deliverable, Vienna. 
Nivyevskiy O., von Cramon-Taubadel S., 2006, Rural Non-Farm Employment in Ukraine. Agriculture in the Face of Changing Markets, Institutions and Policies: Challenges and Strategies, Studies on the Agricultural and Food Sector in Central and Eastern Europe, 33, IAMO, Halle (Saale), pp. 484-496.

OECD, 2006, The New Rural Paradigm: Policies and Governance, Paris, OECD Publishing.

RuralJobs project, 2013, Final Report, http://cordis.europa.eu/documents/documentlibrary /137034081EN8.zip

Saraceno E., 1999, Creating Jobs in Rural Areas. The LEADER Way to Job Creation, http://ec.europa. eu/agriculture/rur/leader2/rural-en/biblio/emploi/art02.htm

Sedik D., 2003, Rural Finance without Markets in Ukraine, 1991-2000, ESA Working Paper 03-01, FAO, Rome, ftp://ftp.fao.org/docrep/fao/007/ae034e/ae034e00.pdf

State Statistics Committee of Ukraine, 2003, Statistical Yearbook of Ukraine for 2002, Kyiv.

State Committee of Ukraine for Statistics, 2006a, Social and Economic Conditions of Rural Settlements in Ukraine, Kyiv.

State Statistics Committee of Ukraine, 2006b, Statistical Yearbook of Ukraine for 2005, Kyiv.

State Statistics Committee of Ukraine, 2008, Statistical Yearbook of Ukraine for 2007, Kyiv.

State Statistics Committee of Ukraine, 2009a, Economic Activity of the Population of Ukraine 2008, Kyiv.

State Statistics Committee of Ukraine, 2009b, Statistical Yearbook of Ukraine for 2008, Kyiv.

State Statistics Committee of Ukraine, 2010a, Economic Activity of the Population of Ukraine 2009, Kyiv.

State Statistics Committee of Ukraine, 2010b, Social Indicators of the Standard of Living of the Population 2009, Kyiv.

State Statistics Committee of Ukraine, 2010c, Statistical Yearbook of Ukraine for 2009, Kyiv.

State Statistics Service of Ukraine, 2011, Statistical Yearbook of Ukraine for 2010, Kyiv.

State Statistics Service of Ukraine, 2012a, Expenditures and Resources of Households of Ukraine in 2011, Kyiv.

State Statistics Service of Ukraine, 2012b, Statistical Yearbook of Ukraine for 2011, Kyiv.

State Statistics Service of Ukraine, 2013a, Agriculture of Ukraine 2012, Kyiv.

State Statistics Service of Ukraine, 2013b, Economic Activity of the Population of Ukraine 2012, Kyiv.

State Statistics Service of Ukraine, 2013c, Population of Ukraine in 2012, Kyiv.

State Statistics Service of Ukraine, 2013d, Social Indicators of the Standard of Living of the Population 2012, Kyiv.

State Statistics Service of Ukraine, 2013e, Statistical Yearbook of Ukraine for 2012, Kyiv.

The International Bank for Reconstruction and Development / The World Bank, 2007, World Development Report 2008: Agriculture for Development, Washington, D.C.

The International Bank for Reconstruction and Development / The World Bank, 2013, Doing Business 2014. Economy Profile: Ukraine, Washington, D.C.

Yakuba K., 2007, The Vital and Labor Potential of the Rural Population of Ukraine. Theory, Methodology, Practice, Institute of Agrarian Economics, Kyiv. 
http://rcin.org.pl 